\title{
The Impact of the Investment Environment on Foreign Direct Investment (FDI) in the European Transition Economies
}

\section{Bersan Haliti*, Safet Merovci**}

\section{Abstract}

The main objective of this paper is to investigate the impact of the investment environment on FDI in transition economies in Europe, through the usage of dynamic panel methodology, due to the persistence of the endogeneity issues. Further, three main factors have been determined affecting the FDI in 15 developing countries through the time span 2009-2016 as Control of Corruption, Political Stability and Absence of Violence/Terrorism and Distance to frontier score (Doing Business) having positive and significant effect on attracting FDI in these transition countries. Also as pull factors are used GDP per capita, profit tax rate showing positive and significant effect on FDI flows, while unemployment rate was positive but does not have a significant role in the attraction of FDI flows in European transition countries.

In addition, to our best knowledge this paper is among the first that attempts to investigate this relationship in this set of countries by employing the dynamic panel methodology using differenced GMM model as well as employing Distance to frontier score (Doing Business) as one of investment environment factors that impact FDI flows for this set of 15 countries.

Furthermore, such findings will contribute to the existing literature by using these instruments to measure their impact on FDI attractiveness on European transition economies.

Keywords: FDI, investment environment, dynamic panel, transition, differenced GMM.

JEL code: C23, D73, F21.

\section{INTRODUCTION}

Decently the nexus between investment Tenvironment factors and FDI flows has attracted the attention of many scholars due to the important role that investment environment plays on FDI attractiveness process.

Taking into consideration the importance of the FDI flow attractiveness in transition economies and the effects of investment environment on this process has been emphasized by many scholars, although a large body of existing literature has been utilizing fixed static panel data methodology, thus neglecting the dynamic nature among this nexus. In addition, there exist few papers that have investigated the dynamic relationship among different factors from investment environment and FDI flows, through the employment of Arellano and Bond

${ }^{1}$ PhD Candidate, Address: Prishtinë, Kosovo

${ }^{2}$ Associate professor, PhD, University of Prishtina, Faculty of Economics, Kosovo, Address: Prishtinë, Kosovo 


\section{Articles}

(1991) differenced GMM method. To our best knowledge, this represents the first paper to address this methodology for analyzing this link among these European transition countries. What is more, this paper analyzes the impact of investment environment on the FDI flows attractiveness through the dynamic panel methodology of Arellano and Bond (1991), used also by Daude \& Stein (2007), Busse \& Hefeker (2007), Okada (2013), Asiedu (2013), Kurul \& Yalta (2017).

Moreover, this paper will contribute to the existing literature in several ways: firstly, different dimensions of investment environment are taken into consideration, rather than just focusing only on one factor like in several papers (Jensen 2003; Ahlquist 2006). Next, the set of countries covered in this paper is formed from 15 European transition countries for a recent time period 2009 - 2016. Finally, Distance to frontier score (Doing Business) is for the first time used as one of investment environment factors in this set of data.

The variables used in this paper are: Control of Corruption, Political Stability and Absence of Violence/Terrorism, Distance to frontier score (Doing Business) and as pull factors are used GDP per capita, unemployment rate and profit tax rate. These variables are treated, because they are considered as the most important for attracting Foreign Direct Investment (FDI) in these transition countries.

One of the scientific innovations of this research is the treatment of variables Distance to frontier score (Ease of Doing Business) which is used for the first time as such for this group of states.

Distance to frontier score (Ease of Doing Business) ${ }^{1}$ illustrates the distance of an economy to the "frontier," which represents the best performance observed on each Doing Business topic across all economies and years included since 2005. An economy's distance to frontier is indicated on a scale from 0 to 100 , where 0 represents the lowest performance and 100 the frontier.

Many authors have addressed some of the indicators of Distance to frontier score, but not this indicator as a whole, which includes 10 indicators.

The results of this research show that Control of Corruption, Political Stability and Absence of Violence/Terrorism and Distance to frontier score (Doing Business) have shown a positive impact on attracting FDI. Also factors like GDP per capita and profit tax rate have shown a positive impact on FDI, while unemployment rate was positive but does not have a significant role on the attraction of FDI flows in European transition countries.

The structure of the paper is organized as follows: section 2 presents a brief overview regarding the relevant literature of the nexus between investment environment and FDI flows. Section 3 is dedicated to the research methodology and data, while the empirical findings are presented in section 4. The last section deals with the conclusions and recommendations implied from the empirical findings.

\section{LITERATURE REVIEW}

Many scholars have conducted research on various factors of investment environment and Foreign Direct Investment:

In his study Bailey (2018) investigates the relationship between institutional factors and FDI flows, suggesting that there is a positive relationship between political stability and FDI flows. Moreover, institutional factors such as corruption, tax rates had negative relationship with FDI flows. Further, Kurul \& Yalta (2017) in their study consisting of 113 developing countries conducted for the time period 20022012 (including most of the countries treated

\footnotetext{
${ }^{1}$ World Bank. 2019, Doing Business, https://www.doingbusiness.org. Obtained from web page on date: 05.01.2019.
} 


\section{Articles}

in our research, such as, Albania, Bosnia and Herzegovina, Bulgaria, Croatia, Latvia, North Macedonia, Lithuania, Romania, while other countries such as Poland, the Czech Republic, Montenegro, Serbia, Slovenia, Estonia, Slovakia were not included) reveal that control of corruption has a significant and positive impact on FDI flows.

It is well known that multinational companies prefer stable, credible and honest political institutions (Globerman \& Shapiro, 2003). Moreover, political instability makes the country less attractive because it creates an unpredictable environment (Büthe \& Milner, 2008; Loree \& Guisinger, 1995; Woodward \& Rolfe, 1993). Also, political instability significantly reduces the inflow of foreign direct investment (Schneider \& Frey, 1985), as is ahown in the survey conducted for 80 least developed countries. Also Campos \& Nugent (2003), Loree \& Guisinger (1995), Sethi et al., (2003) and Woodward \& Rolfe (1993); suggest that political stability has a significant positive relationship with FDI flows.

Moreover, Gani (2007) uses panel data estimates for some Latin American countries and concludes that control of corruption and political stability has positive effects on FDI flows. While on the other hand, the findings of Globerman \& Shapiro (2003); Kobrin (1976) suggest that political stability does not affect the flows of FDI.

An effective, impartial and transparent legal system that protects property rights is virtually a prerequisite for FDI consideration (Globerman \& Shapiro, 2003; Sethi et al., 2002, 2003). Corruption creates inefficiencies in markets and resource allocation, which increases production and management costs and hampers FDI (Cuervo-Cazurra, 2006; Gastanaga et al., 1998; Habib \& Zurawicki, 2002; Robertson \& Watson, 2004). Research from this paper also reveals that investors who are exposed to bribery in their countries
The Impact of the Investment Environment on Foreign Direct Investment (FDI) in the European Transition Economies

cannot be hindered by corruption abroad, but instead seek places where corruption is widespread.

Asiedu (2006) after a study in 22 countries in Africa for the period 1984-2000 points out that institutional inefficiency such as corruption and political instability hamper FDI inflows. While the authors Al-Egger \& Winner (2005), after a study of 73 developed and least developed states for the period 1995-1999, point out that there is a positive relationship between corruption and FDI, so corruption is a stimulus for FDIs.

Shahzad \& Al-Swidi (2013) suggest that the growth of the GDP ratio has a positive impact on the inflow of Foreign Direct Investment in Pakistan. This research was conducted for the time period 1991-2011. Also the results from research for the time period 1980-2013, made by Alshamsi et al. (2015) claims that GDP per capita has a positive impact on $\mathrm{FDI}$, in the United Arab Emirates economy. Moreover, Boateng, et al. (2015) suggest that with regard to the real and sectoral GDP, they have positive impacts on FDI.

Strat et al. (2015) conducted a study for 13 recently accepted European Union countries for the time period 1991-2012 and emphasize that in six countries, as Lithuania, Latvia, Croatia, Slovenia, Poland (included in our research) and Cyprus, no causality relationship was identified between unemployment and FDI. Yet in Romania, Czech Republic and Slovakia there exists a positive relationship between unemployment and Foreign Direct Investments. Another study, conducted by Aktar, Demirci \& Öztürk (2009), reports the existence of no causal relationships between unemployment and the inflow of foreign direct investment for the Turkish economy. The same conclusion was reached by Saray (2011) when he analyzed data stretching from 1970 until 2009, again regarding the Turkish economy. 


\section{Articles}

Unlike the aforementioned authors, Boateng, et al. (2015) in their study with the focus on Norway for the time period 1986-2009 point out that there is a significant negative link between unemployment and FDI flows.

Olival (2012) used panel data for 20042009 to find a link between various indicators of Doing Business and FDI for 144 developing countries and 33 developed countries. The major implication is that in general, a better rated business environment is more likely to attract greater amounts of FDI, especially in the case of developing countries. Moreover, institutional areas that are most likely to influence inward FDI are: starting a business, registering a property and trading across borders. A study by Anderson \& Gonzalez (2013) opines that higher DTF scores are associated with high FDI inflows.

From the review of the literature that has been made, regarding the profit tax variable, this variable has not been encountered before in terms of attracting FDI. But tax treatment has been done differently by scholars in order to reflect on FDI. Sedmihradsky \& Klazar, (2002) emphasize most governments of the Central and East European countries adopted tax measures in the 1990s to support foreign direct investments. Such measures usually include 10-year tax holidays and exemption from import duties. They are mostly accompanied by grants for building infrastructure and creation of new jobs. As their data indicate and as the statistical test has proved, the incentives are effective in attracting new FDI to the countries. Also from their research conducted for some Emerging EU Economies, Göndör \& Nistor (2012) pointed out that fiscal policy is a major factor influencing foreign direct investment.

\section{RESEARCH METHODOLOGY AND DATA}

The empirical analysis of this paper is based on a set of 15 countries for the time period 2009-2016 in order to investigate the relationship between investment environment and FDI flows.

The countries involved in this research are: 10 states that are in the transition phase but are part of the European Union such as Poland, Czech Republic, Lithuania, Bulgaria, Croatia, Romania, Slovenia, Estonia, Latvia and the Slovak Republic, and 5 Western Balkans states which are in transition phase but are not part of the European Union. They are Albania, Bosnia and Herzegovina, North Macedonia, Montenegro, Serbia.

Table 1: Definition of variables and their sources

\begin{tabular}{|l|l|l|l|l|l|}
\hline Variable name & Acronym & Variable type & $\begin{array}{l}\text { Expected } \\
\text { effects }\end{array}$ & Log & Source \\
\hline Foreign Direct Investment & FDI & Dependent & & Yes & World Bank \\
\hline $\begin{array}{l}\text { First lag of Foreign Direct } \\
\text { Investment }\end{array}$ & FDI (-1) & Dependent & & Yes & World Bank \\
\hline Control of Corruption & CC & Independent & + & Yes & World Bank \\
\hline $\begin{array}{l}\text { Political Stability and } \\
\text { Absence of Violence/Terrorism }\end{array}$ & PS & Independent & + & Yes & World Bank \\
\hline Distance to Frontier Score & DFS & Independent & + & Yes & World Bank \\
\hline GDP per capita & GDPcap & Independent & + & Yes & IMF \\
\hline Unemployment & UNEMP & Independent & - & Yes & World Bank \\
\hline Profit tax & PT & Independent & - & Yes & World Bank \\
\hline
\end{tabular}

Source: Authors' compilation 


\section{Articles}

From the table above can be seen that as dependent variable is set the FDI net inflow as percentage of GDP, annual data are collected from the World Bank, while in the framework of the investment environment are taken variables such as: Control of Corruption, Political Stability and Absence of Violence/Terrorism and
The Impact of the Investment Environment on Foreign Direct Investment (FDI) in the European Transition Economies

Distance to frontier score (Doing Business). Also as pull factor in attraction FDI are taken variables as GDP per capita (the data are obtained from the International Monetary Fund - IMF), Unemployment rate and Profit tax rate.

Further, the basic model of this paper is shown below:

$\mathrm{FDI}_{i t}=\beta_{1} \mathrm{FDI}_{i t-1}+\beta_{2} \mathrm{CC} i t+\beta_{3} \mathrm{PS} i t+\beta_{4} \mathrm{DFS}_{i t}+\beta_{5} \mathrm{GDPC} i t+\beta_{6} \mathrm{UNEMP} i t+\beta_{7} \mathrm{PT} i t+\mathrm{u}_{i t}$

where: $F D I_{i t}$ represents the Foreign Direct Investments as percentage of GDP,

$F D I_{i t-1}$ represents the first lag of Foreign Direct Investments, thus the main independent variables,

$\beta_{2}$ CCit,represents Control of Corruption;

$\beta_{3}$ PSit, represents Political Stability and Absence of Violence/Terrorism;

$\beta_{4}$ DFSit, represents Doing Business, respectively Distance to Frontier (DTF) ${ }^{2}$ score;

Below are presented vector of control variables as pull factors attracting FDI:

$\beta_{5}$ GDPCit, represents GDP per capita;

$\beta_{6} \mathrm{UNEMP} i t$, represents Unemployment Rate and

$\beta_{7}$ PTit, represents Profit Tax rate. These three recent variables may affect the dependent variable;

$u_{i t}$, represents the error term over years.

Due to the endogeneity issue that might occur between the dependent variable and explanatory variables as well as the autocorrelation problem when one lagged dependent variable is included in the regression, this paper employs Arellano and Bond (1991) differenced GMM estimator that was initially suggested by Holtz-Eakin et al.(1988). Thus, similar to OLS estimators, fixed effects estimators are weak instruments, thus they are likely to be biased. This technique gives more accurate results compared to the static panel.

Moreover, in the model are included some pull factors such as GDP per capita, unemployment rate and profit tax rate. In addition, all data was obtained from databases of reputable international institutions such as World Bank (WB) and International Monetary Fund (IMF). It took into account also the study of Bailey (2018), who conducted research on the link between institutional factors and FDI withdrawal. Kurul \& Yalta, (2017) and their study of 113 developing countries for some variables are taken into account for this research.

\section{EMPIRICAL FINDINGS}

Table 2 shows the descriptive statistics of the dataset used in the analyses. From the results it can be seen the average of dependent variable is 1.22 while maximum value is 3.61 . The data are present in the natural logarithm and for this reason the data in descriptive statistics are close in value.

Table 2: Descriptive Statistics

\begin{tabular}{|l|l|l|l|l|l|}
\hline VARIABLES & OBS & MEAN & STD.DEV & MIN & MAX \\
\hline In FDIOFGDP & 120 & 1.222465 & .8895384 & -2.625887 & 3.617628 \\
\hline In CC & 120 & 4.065379 & .2393535 & 3.278664 & 4.477118 \\
\hline
\end{tabular}

\footnotetext{
2 Includes 10 indicators from Ease of Doing Business, as: starting a business, dealing with construction permits, getting electricity, registering property, getting credit, protecting minority investors, paying taxes, trading across borders, enforcing contracts, resolving insolvency.
} 
Articles

\begin{tabular}{|l|l|l|l|l|l|}
\hline VARIABLES & OBS & MEAN & STD.DEV & MIN & MAX \\
\hline In SPOL & 120 & 4.058977 & .3391139 & 3.014512 & 4.489754 \\
\hline In EDB & 120 & 4.231802 & .0996306 & 3.945458 & 4.399252 \\
\hline In GDPcap & 120 & 9.290982 & .6817277 & 8.277837 & 10.95009 \\
\hline In UNEMP & 120 & 2.556379 & .490368 & 1.386294 & 3.471967 \\
\hline In PT & 120 & 2.16267 & .34936 & 1.526056 & 2.85647 \\
\hline
\end{tabular}

Source: Authors' compilation

The analyzed relationship between the investment environment and foreign direct investments flows as modeled in the equation

1 above has suggested the following results as presented in the Table 3 :

Table 3: Results from differenced GMM (Arellano and Bond)

\section{Dependent variable In fdi}

\begin{tabular}{|l|l|l|l|l|l|l|}
\hline Variable & Coefficient & St.error & t-statistics & Prob & AR(1) & AR(2) \\
\hline In fdi (-1) & .5669352 & .1408224 & 4.03 & 0.000 & 0.011 & 0.632 \\
\hline In cc & $1.515092^{*}$ & 4.085249 & 0.37 & 0.071 & 0.011 & 0.632 \\
\hline In spol & $0.467616^{*}$ & .8340895 & 0.56 & 0.078 & 0.011 & 0.632 \\
\hline In dfs & $0.024822^{* * *}$ & 2.099094 & 0.01 & 0.010 & 0.011 & 0.632 \\
\hline In gdpcap & $1.039179 * *$ & .8804258 & 1.18 & 0.021 & 0.011 & 0.632 \\
\hline In unemp & .1129329 & .8367161 & 0.13 & 0.893 & 0.011 & 0.632 \\
\hline In pt & $0.780472 * * *$ & .6098222 & 1.27 & 0.004 & 0.011 & 0.632 \\
\hline * & &
\end{tabular}

${ }^{*}$ statistically significant at $90 \%$ level of significance. ${ }^{* *}$ statistically significant at $95 \%$ level of significance. ${ }^{* * *}$ statistically significant at $99 \%$ level of significance. For $\operatorname{AR}(1),=$ there exist no autocorrelation, for $\mathrm{AR}(2)$, = there exist no autocorrelation.

$m 1$ test for AR (1): $p<0.05$ suggests the rejection of the null hypothesis (there is no autocorrelation in the first order in the differenced residuals) so it is acknowledged that there is autocorrelation in the first order.

m2 test for AR (2): $p>0.05$ suggests non-rejection (accepting) the null hypothesis (there is no auto correlation in the second order in the differenced residuals). This supports the validity of the instru ments.

Hansen test of overidentifying restrictions: $\operatorname{chi} 2(4)=2.17$ Prob $>$ chi2 $=0.704$

(Robust, but can be weakened by many instruments.)

Sargan test of overidentifying restrictions: $\operatorname{chi} 2(4)=2.95$ Prob $>$ chi2 $=0.567$

(Not robust, but not weakened by many instruments.)

Number of instruments $=12$

iv( In_gdpcap In_unemp In_pt

Source: Authors' compilation.

The empirical results of the differenced GMM reveal that FDI flows depend on the investment environment of the transition European countries. It is also suggested that the control of corruption has a significant and positive effect on attracting FDI flows. These results are in line with the existing findings: Wei (2000), Asiedu (2006), Kurul \& Yalta (2017) and Gani (2007). 


\section{Articles}

In addition, Political Stability and Absence of Violence/Terrorism also shows significant and positive effect on FDI flows in European transition countries for the time period 2009 2016, consistent with those of Bailey (2018), Shneider \& Frey (1985), Campos \& Nugent (2003), Loree \& Guisinger (1955), Sethi et al (2003), Woodward \& Rolfe (1993), Gani (2007), Buchanan et al. (2012), and opposite to Wheeler \& Mody (1992) that suggest no significant relationship between these variables.

Further, results reveal that Distance to frontier (DTF) score (Doing Business) has significant and positive impact on FDI flows in these transition economies for the time period 2009-2016. In addition, this factor is the main novelty in this research, since to our best knowledge it is the first time that it has been included as Doing Business variable on this set of data. But there are some authors who used ranking in Doing Business or some indicators in attracting FDI. Piwonski (2010) emphasizes that by increasing their country's Doing Business rank one level, a government can bring in over 44 million USD. In the same vein are also the findings of Olival (2012), and Anderson \& Gonzales (2013). Bayraktar (2013) in turn points out that countries which have better records of "doing business" tend to attract more FDI. The improvement in "ease of doing business" indicators in developing countries can have a partial explanatory power in determining higher FDI flows to these countries. While authors such as Alves \& Oliveira (2012) have established that Ease of Doing Business Index (EDBI) is not suitable for investment decisions due to its statistical weaknesses. There is substantial room for improvement in its statistical robustness.

In addition, findings of GDP per capita shows positive and significant effect on FDI flows attraction in European transition economies, which is consistent with those
The Impact of the Investment Environment on Foreign Direct Investment (FDI) in the European Transition Economies

of Shahzad \& Al-Swidi (2013), Alshamsi et al (2015), Boateng et al (2015) Neumayer \& Spess (2005), Kurul and Yalta (2017). Moreover, there are conclusions that unemployment plays a insignificant role on the attraction of FDI flows, in accordance with studies conducted by Strat et al. (2015), Aktar, Demirci \& Öztürk (2009), Saray (2011).

Profit tax rate reveals positive and significant effect on FDI flows in European transition countries. These states have taken incentives (tax reliefs), (some of them examined by Göndör \& Nistor (2012), Sedmihradsky \& Klazar, (2002)) which have impacted that, even though profit tax had grown over the years to these countries. At the same time foreign direct investment (FDI) have grown as result of these tax relief applied from these countries over this time period.

\section{CONCLUSIONS AND RECOMMENDATIONS}

There has been a recent debate among scholars on the impact of the different factors from the investment environment in attracting FDI flows in transition countries. In addition, this paper analyzes the relationship between investment environment and FDI flows in 15 European economies for the time span 20092016, contributing to the existing literature by employing dynamic panel methodology for such country set and time period.

This paper has included three main factors: Control of corruption, Political stability and absence of violence/terrorism and Distance to Frontier (DTF) score (Doing Business) and three pull factors, namely GDP per capita, unemployment rate and profit tax rate.

In addition, all three main factors have revealed positive and significant effect on FDI flows in this set of countries for the time period 2009-2016, which is consistent with a large body of empirical findings. In addition, from the pull factors, only unemployment rate 


\section{Articles}

has shown to have insignificant relationship with the FDI flow, while GDP per capita has shown positive and significant effect in attracting FDI in these countries. This result is in line with a large number of findings related to this relationship between these variables.

Also Profit Tax Rate has shown positive and significant effect on FDI flows. What should be clarified regarding this result is that these states have taken incentive measures (tax reliefs), as mentioned above, thus these measures have impacted, even though profit tax had grown over the years to these countries, while at the same time foreign direct investment (FDI) have grown as result of these tax reliefs applied by these countries over this time period.

In addition, Distance to Frontier Score is the main novelty in this research, since to our best knowledge this is the first time that Doing Business variable has been applied to this set of data. Also Profit Tax has not previously been used as a separate variable from other taxes with regard to this group of countries.

These results reveal that governments in these states should play an important role in the investment policy reforms in their political system in order to attract more FDI inflows. In addition, recommendations for the governments are the following:

- it is essential that governments should provide political stability, given the results of this paper, since political instability affects the FDI decline in this set of countries.

- governments have to take measures to combat corruption in order to lower the rate of corruption in these countries which would provide for the attraction of a higher level of FDI.

- the investment environment should be improved by raising the level (percentage) of Distance to Frontier score, which includes 10 indicators of Doing Business, because by improving this indicator, FDI can be increased in this group of states.

- the level of GDP per capita should be increased in these countries, as the results of this research suggest that the higher the GDP per capita, the higher will be FDI in this group of states.

The above mentioned measures, if taken from the governments of these countries, based on the results of this paper, could have an impact on creating a more favorable environment for attracting a higher level of FDI.

\section{References}

Ahlquist, J.S., 2006. Economic policy, institutions, and capital flows: Portfolio and direct investment flows in developing countries. International Studies Quarterly, 50(3), pp.681-704.

Aktar, I., Demirci, N. and Öztürk, L., 2009. Can unemployment be cured by economic growth and foreign direct investment? Sosyal Ekonomik Araştırmalar Dergisi, 9(17), pp.452467.

Alshamsi, K.H., Hussin, M.R.B. and Azam, M., 2015. The impact of inflation and GDP per capita on foreign direct investment: the case of United Arab Emirates. Investment Management and Financial Innovations, 12(3), pp. 53-74.

Anderson, J. and Gonzalez, A., 2013. Does Doing Business matter for foreign direct investment. Doing Business, pp. 47-50.

Arellano, M. \& Bond, S. (1991). Some test of specification for panel data: Monte Carlo evidence and application to employment equations. Review of Economic Studies, 58, pp. 227-297.

Asiedu, E., 2006. Foreign direct investment in Africa: The role of natural resources, market size, government policy, institutions and 


\section{Articles}

political instability. World economy, 29(1), pp. 63-77.

Asiedu, E., 2013. Foreign direct investment, natural resources and institutions. International Growth Centre.

Bailey, N., 2018. Exploring the relationship between institutional factors and FDI attractiveness: A meta-analytic review. International Business Review, 27(1), pp.139148.

Bayraktar, N., 2013. Foreign direct investment and investment climate. Procedia Economics and Finance, 5, pp.83-92.

Boateng, A., Hua, X., Nisar, S. and Wu, J., 2015. Examining the determinants of inward FDI: Evidence from Norway. Economic Modelling, 47, pp.118-127.

Buchanan, B.G., Le, Q.V. and Rishi, M., 2012. Foreign direct investment and institutional quality: Some empirical evidence. International Review of financial analysis, 21, pp.81-89.

Busse, M. and Hefeker, C., 2007. Political risk, institutions and foreign direct investment. European Journal of Political Economy, 23(2), pp.397-415.

Büthe, T. and Milner, H.V., 2008. The politics of foreign direct investment into developing countries: increasing FDI through international trade agreements? American Journal of Political Science, 52(4), pp.741-762.

Campos, N.F. and Nugent, J.B., 2003. Aggregate investment and political instability: an econometric investigation. Economica, 70(279), pp.533-549.

Cuervo-Cazurra, A., 2006. Who cares about corruption? Journal of International Business Studies, 37(6), pp.807-822.

Daude, C. and Stein, E., 2007. The quality of institutions and foreign direct investment. Economics \& Politics, 19(3), pp.317-344.
The Impact of the Investment Environment on Foreign Direct Investment (FDI) in the European Transition Economies

Egger, P. and Winner, H., 2005. Evidence on corruption as an incentive for foreign direct investment. European Journal of Political Economy, 21(4), pp.932-952.

Gani, A., 2007. Governance and foreign direct investment links: evidence from panel data estimations. Applied economics letters, 14(10), pp.753-756.

Gastanaga, V.M., Nugent, J.B. and Pashamova, B., 1998. Host country reforms and FDI inflows: How much difference do they make? World development, 26(7), pp.12991314.

Globerman, S. and Shapiro, D., 2003. Governance infrastructure and US foreign direct investment. Journal of International Business Studies, 34(1), pp.19-39.

Göndör, M. and Nistor, P., 2012. Fiscal policy and foreign direct investment: evidence from some emerging EU economies. ProcediaSocial and Behavioral Sciences, 58, pp.12561266.

Habib, M. and Zurawicki, L., 2002. Corruption and foreign direct investment. Journal of International Business Studies, 33(2), pp.291307.

Holtz-Eakin, D., Newey, W. and Rosen, H.S., 1988. Estimating vector autoregressions with panel data. Econometrica 56 (6): 1371 1395https://doi. org/10.2307/1913103.

International Monetary Fund (www.imf.org) Obtained from web page on date: 20.01.2019. Jensen, N.M., 2003. Democratic governance and multinational corporations: Political regimes and inflows of foreign direct investment. International organization, 57(3), pp.587-616.

Kobrin, S.J., 1976. The environmental determinants of foreign direct manufacturing investment: an ex post empirical analysis. Journal of International Business Studies, 7(2), pp.29-42. 
Kurul, Z. and Yalta, A.Y., 2017. Relationship between Institutional Factors and FDI Flows in Developing Countries: New Evidence from Dynamic Panel Estimation. Economies, 5(2), p.17.

Loree, D.W. and Guisinger, S.E., 1995. Policy and non-policy determinants of US equity foreign direct investment. Journal of International Business Studies, 26(2), pp.281299.

Neumayer, E. and Spess, L., 2005. Do bilateral investment treaties increase foreign direct investment to developing countries? World development, 33(10), pp.1567-1585.

Okada, K., 2013. The interaction effects of financial openness and institutions on international capital flows. Journal of Macroeconomics, 35, pp.131-143.

Olival, A.I.D.N., 2012. The influence of Doing Business' institutional variables in Foreign Direct Investment (Doctoral dissertation).

Pinheiro-Alves, R. and Zambujal-Oliveira, J., 2012. The Ease of Doing Business Index as a tool for investment location decisions. Economics Letters, 117(1), pp.66-70.

Piwonski, K., 2010. Does the 'Ease of Doing Business' In a Country Influence its Foreign Direct Investment Inflows?

Robertson, C.J. and Watson, A., 2004. Corruption and change: The impact of foreign direct investment. Strategic Management Journal, 25(4), pp.385-396.

Saray, M.O., 2011. Doğrudan yabancı yatırımlar-istihdam ilişkisi: Türkiye örneği. Maliye Dergisi, 61(2), pp.381-403.
Schneider, F. and Frey, B.S., 1985. Economic and political determinants of foreign direct investment. World development, 13(2), pp.161175.

Sedmihradsky, M. and Klazar, S., 2002. Tax competition for FDI in Central-European countries.

Sethi, D., Guisinger, S. E., Phelan, S. E., \& Berg, D. M. (2003). Trends in foreign direct investment flows: A theoretical and empirical analysis. Journal of International Business Studies, 34(4), 315-326.

Shahzad, A. and Al-Swidi, A.K., 2013. Effect of Macroeconomic Variables on the FDI inflows: The Moderating Role of Political Stability: An Evidence from Pakistan. Asian Social Science, 9(9), p.270.

Strat, V.A., Davidescu, A. and Paul, A.M., 2015. FDI and the unemployment-A causality analysis for the latest EU members. Procedia Economics and Finance, 23, pp.635-643.

Wei, S.J., 2000. How taxing is corruption on international investors?. Review of economics and statistics, 82(1), pp.1-11.

Wheeler, D. and Mody, A., 1992. International investment location decisions: The case of US firms. Journal of international economics, 33(1-2), pp.57-76.

Woodward, D.P. and Rolfe, R.J., 1993. The location of export-oriented foreign direct investment in the Caribbean Basin. Journal of international business studies, 24(1), pp.121144.

World Bank. 2019, Doing Business, https:// www.doingbusiness.org. Obtained from web page on date: 05.01.2019. 